\title{
Barriers to the Use of Mobile Health in Improving Health Outcomes in Developing Countries: Systematic Review
}

Clemens Kruse, MHA, MSIT, MBA, PhD; Jose Betancourt, DPH; Stephanie Ortiz, BHA; Susana Melissa Valdes Luna, BA, MHA; Inderdeep Kaur Bamrah, BA, MHA; Narce Segovia, BA, MHA

School of Health Administration, Texas State University, San Marcos, TX, United States

Corresponding Author:

Clemens Kruse, MHA, MSIT, MBA, PhD

School of Health Administration

Texas State University

601 University Dr

Encino Hall 250

San Marcos, TX, 78666

United States

Phone: 12103554742

Fax: 15122458712

Email: scottkruse@txstate.edu

\begin{abstract}
Background: The use of mobile health (mHealth) technologies to improve population-level health outcomes around the world has surged in the last decade. Research supports the use of mHealth apps to improve health outcomes such as maternal and infant mortality, treatment adherence, immunization rates, and prevention of communicable diseases. However, developing countries face significant barriers to successfully implement, sustain, and expand mHealth initiatives to improve the health of vulnerable populations.
\end{abstract}

Objective: We aimed to identify and synthesize barriers to the use of mHealth technologies such as text messaging (short message service [SMS]), calls, and apps to change and, where possible, improve the health behaviors and health outcomes of populations in developing countries.

Methods: We followed the Preferred Reporting Items for Systematic Reviews and Meta-Analyses checklist. Deriving search criteria from the review's primary objective, we searched PubMed and CINAHL using an exhaustive terms search (eg, mHealth, text messaging, and developing countries, with their respective Medical Subject Headings) limited by publication date, English language, and full text. At least two authors thoroughly reviewed each article's abstract to verify the articles were germane to our objective. We then applied filters and conducted consensus meetings to confirm that the articles met the study criteria.

Results: Review of 2224 studies resulted in a final group of 30 articles for analysis. mHealth initiatives were used extensively worldwide for applications such as maternal health, prenatal care, infant care, HIV/AIDS prevention, treatment adherence, cardiovascular disease, diabetes, and health education. Studies were conducted in several developing countries in Africa, Asia, and Latin America. From each article, we recorded the specific health outcome that was improved, mHealth technology used, and barriers to the successful implementation of the intervention in a developing country. The most prominent health outcomes improved with mHealth were infectious diseases and maternal health, accounting for a combined 20/30 (67\%) of the total studies in the analysis. The most frequent mHealth technology used was SMS, accounting for 18/30 (60\%) of the studies. We identified 73 individual barriers and grouped them into 14 main categories. The top 3 barrier categories were infrastructure, lack of equipment, and technology gap, which together accounted for 28 individual barriers.

Conclusions: This systematic review shed light on the most prominent health outcomes that can be improved using mHealth technology interventions in developing countries. The barriers identified will provide leaders of future intervention projects a solid foundation for their design, thus increasing the chances for long-term success. We suggest that, to overcome the top three barriers, project leaders who wish to implement mHealth interventions must establish partnerships with local governments and nongovernmental organizations to secure funding, leadership, and the required infrastructure.

(J Med Internet Res 2019;21(10):e13263) doi: 10.2196/13263 


\section{KEYWORDS}

health outcomes; telemedicine; text messaging; communication barriers; developing countries; treatment outcome

\section{Introduction}

\section{Background}

Mobile devices are a cheap source of technology for addressing health care needs in developing countries. With the expansion of technology, mobile health (mHealth) is a tool that can be used to exchange health information for improving health outcomes through short message service (SMS) text messaging, mobile apps, and calls [1]. mHealth offers simplicity, efficiency, and effectiveness to patients due to its ability of rapid communication. mHealth intervention is a useful tool due to the ability to be accessible at the user's convenience. Mobile apps can be used to assess and measure the impact of a specific disease or may actually prevent a specific illness from occurring. A simple text can communicate, store, retrieve, and remind patients of their health status or deliver messages that promote healthy behaviors and choices. It is an inexpensive tool that can reduce the disparities of health in developing countries. Health care professionals now use smartphones or tablet computers to accomplish tasks for which they once used to need a pager or a personal digital assistant [2,3].

\section{Definition of Key Terms}

The term barrier is defined as "something that separates one thing from another" [4]. It is anything that prevents a certain goal from being achieved [4]. The second term, mHealth, is defined as a "medical and public health practice supported by mobile devices, such as mobile phones, patient monitoring devices, personal digital assistants, and other wireless devices" [5]. A developing country is a country that has a slow rate of industrialization, low per capita income, high unemployment, high poverty rate, and low standard of living [6]. Developing countries usually rely on developed countries for their economic growth and prosperity [6]

\section{Rationale for the Review}

mHealth is a tool that has had a positive impact on developed countries and has contributed to improving the health outcomes of populations around the world [7]. Specifically, researchers have focused on SMS in health care, and leading health organizations recommend its use [8]. Around the globe, mobile-cellular subscriptions will soon match the number of the population worldwide and are expected to continue to increase [9]. This is especially true in the developing world, where the market has not yet reached saturation [9]. mHealth has closed the gap in the digital divide in low-resource areas [10]. In the developing world, the World Health Organization reported a shortage of health care workers in 57 countries, resulting in a clear opportunity for innovative and effective solutions to help improve the health outcomes of their most vulnerable populations [11]. Mobile technology devices such as tablets, phones, computers, and tracking devices can be used to support and enhance health care in developing countries. The use of text messaging to promote healthy behaviors and healthy choices can be considered a groundbreaking component in improving population and community health.

\section{Context of Other Evidence}

Many studies have been carried out to determine the efficiency of mHealth in developing countries. A literature review of SMS-supported interventions for surveillance, management, treatment compliance, and prevention of noncommunicable diseases in India, South Africa, and Kenya found mobile phones to be well accepted by the population; however, high-quality intervention designed studies were needed [12]. In Nigeria, mobile device questionnaires were used to understand the perceptions of women at high risk of maternal death; although over $90 \%$ of women owned mobile phones, innovative methods were lacking to strengthen the delivery of maternal health information to those hard-to-reach populations [13]. In Zambia, SMS was found to have the potential to diagnose HIV early in infants by accelerating the delivery of results of blood sample testing to clinics, but the identification of lack of mobile phone ownership during the design of the study was found to hinder the success of the intervention [14].

In China, a smartphone app and text messaging were used to improve vaccination coverage among children, as well as the consumption of infant micronutrient powder packets [15]. Caregivers' suspicious beliefs and lack of acceptability were the major causes negatively affecting the success of the mHealth intervention [16,17]. In remote areas of Vietnam, the mMom app was used to improve pregnant women's maternal and infant health knowledge. An anticipated challenge was the high level of integration among local partners that required constant communication and engagement for coordination of the mHealth initiative [3].

An exploratory qualitative study conducted in Latin America and the Caribbean sought to further understand the needs of underserved populations and their exposure to public health interventions that used information and communications technologies to highlight the scarcity of such tools to reduce inequities. The greatest challenges were the lack of sustainability for financial and technical resources due to the unreliability of sustained external funding, poor intervention design caused by the resistance of precedents, and lack of technological literacy among participants unfamiliar with the use of information and communications technologies [18].

A study designed for primary prevention of hypertension in Argentina, Guatemala, and Peru found challenges that consisted of the unacceptability of mHealth innovations by the targeted communities, and emphasized the need to tailor the interventions to potential literacy challenges attributed to lack of understanding of cultural context [19]. In Brazil, a mobile phone-based intervention to promote prenatal care practices found that only one-fifth of women eligible for the study were actually interested in participating [19]. In Tajikistan, Bolivia, and Palestine, a behavioral change intervention was deployed using text messages to bring awareness of using contraceptives among the young to prevent unwanted pregnancies [20]. Negative attitudes toward and beliefs about contraception, including the cultural stigma of having sex before marriage, 
being judged, and confidentiality concerns, limited participant discussion of contraception with providers [21]. In urban and rural areas of Guatemala, text messages were used to remind parents of infants to attend vaccination visits and decrease unnecessary morbidity [22]. This study concluded that client preference for delivery modalities such as a combination of text messaging and phone calls should have been considered to reach the maximum amount of the targeted population [22].

\section{Objective}

While other studies have focused on the potential benefits of mHealth in developing countries, our literature review sought to define the barriers that impede the successful application of mHealth (eg, SMS, cell phones, apps) interventions that aim to improve health outcomes of a population in diverse developing countries around the world. This knowledge may serve as a useful tool for project leaders to consider when planning or designing future mHealth interventions to strengthen the chances of long-term, sustainable success in the community. To analyze the use of mHealth in developing countries, more studies need to examine the different types of barriers these countries face. We conducted this literature review to determine what type of mHealth initiatives are more popular in developing countries, as well as the outcomes and barriers identified by the respective article authors. We aimed to provide a clearer understanding of what initiatives have the best supporting evidence of improving health outcomes by using mHealth approaches and of the resources developing countries require to foster the long-term and sustainable success of these projects.

\section{Methods}

\section{Protocol Registration and Eligibility Criteria}

This review followed the Preferred Reporting Items for Systematic Reviews and Meta-Analyses (PRISMA) guidelines (Multimedia Appendix 1) [23]. We did not register the review. The main objective was to identify and synthesize the barriers to the use of mHealth to improve the health outcomes in developing countries. Articles were eligible for review if they met criteria such as having a health outcome and involving the use of mHealth technology in a developing country. We analyzed articles only if (1) the full-text article was available, (2) the article related to humans, (3) the article was published between 2008 and 2018, and (4) the article was written in English. Exclusion criteria for this review were systematic reviews, articles unrelated to the objective of the review, and no direct health outcome being involved. We did not consider for this review any studies that were in progress. Finally, we removed duplicate articles from the literature matrix.

\section{Information Sources and Search}

In addition to reporting this review in accordance with the PRISMA guidelines, we conducted it using techniques of the Assessment of Multiple Systematic Reviews [24]. We searched PubMed and CINAHL with an exhaustive search string comprising Medical Subject Headings (MeSH), due to their widespread availability, and Boolean operators. Multimedia Appendix 2 provides a detailed list of MeSH terms. We conducted searches for this literature review in September 2018.

\section{Risk of Bias in Individual Studies}

Our methods did not enable randomization, so to control for selection bias, we conducted the search using exhaustive MeSH terms, which are widely used in databases used for literature research. To avoid influencing each other's individual opinions, each researcher recorded his or her findings independently. We calculated a kappa statistic to measure interrater reliability, which refers to the agreement and consistency of article selection. The kappa was .78 , which reflects a moderate agreement between the reviewers $[25,26]$.

\section{Results}

\section{Study Selection, Data Collection Process, and Data Items}

Figure 1 illustrates the search and selection process in each database. The initial search in PubMed resulted in 535 articles, and in CINAHL the search produced 1689 articles. The total number of articles obtained from both search engines was 2224 . Then, after applying limiters, we narrowed the PubMed results down to 144 articles and CINAHL to 145 articles. All 289 abstracts were screened by at least two reviewers. Reviewers screened abstracts recording their individual observations and recommendations to either include or exclude each article. A consensus meeting was then held to arrive at an agreement on the selected articles. If there was a disagreement, a third author's vote was required to reach consensus. We produced a list of 58 abstracts germane to the objective of the review. We distributed these articles among our team in a manner that ensured each article was analyzed by at least two reviewers. A second consensus meeting arrived at a final group of articles for analysis of 30 . The other articles were eliminated after a full reading. 
Figure 1. Preferred Reporting Items for Systematic Reviews and Meta-Analyses flow diagram of the literature search and selection process.

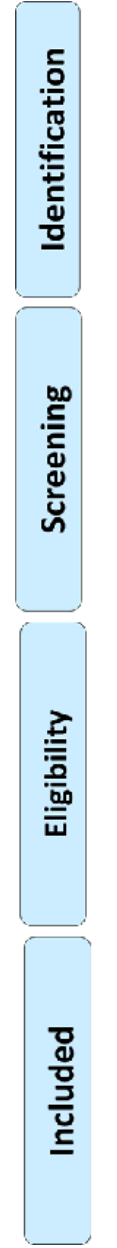

Records identified through database
searching

$(n=2224)$
Additional records identified through other sources $(n=0)$

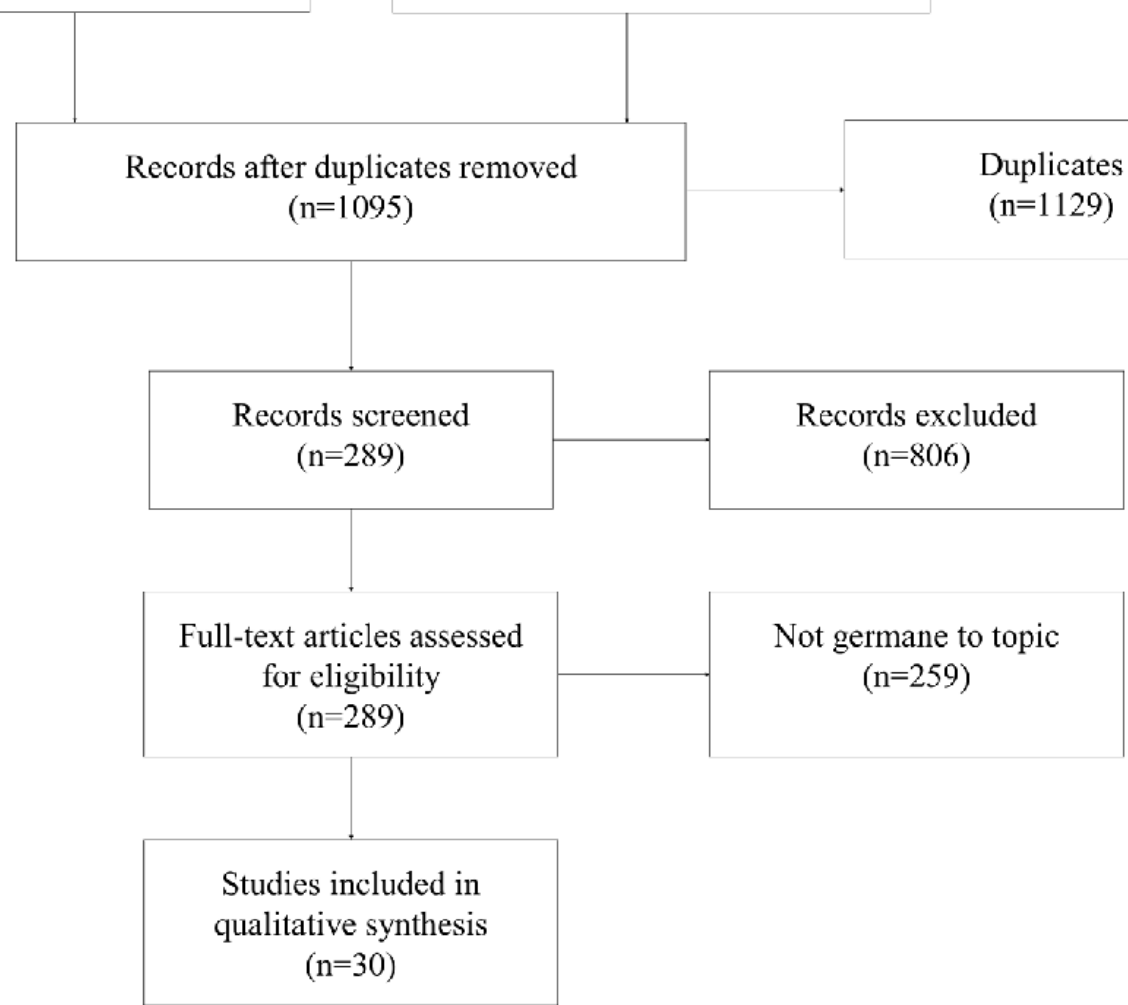

\section{Study Selection and Characteristics}

Between September and November 2018, we reviewed the 30 articles germane to this review's objective of defining the barriers to implementing mHealth interventions in developing countries. Results included mHealth initiatives covering health outcomes such as prenatal care, infectious diseases, medication adherence, appointment reminders, and chronic diseases education. The articles in the group for analysis reported interventions piloted across several developing countries around the world. We divided the 30 articles among the reviewers for analysis by at least two reviewers. We held group consensus meetings to facilitate discussion of individual barriers identified in the articles.

\section{Results of Individual Studies and Synthesis of Results}

We analyzed the articles to determine the health outcomes most commonly improved with mHealth interventions, the most used mHealth technology, and, most importantly, the barriers that hindered the adoption or impact of the mHealth interventions. We break down each of the findings to provide a comprehensive vision for future leaders who wish to implement mHealth interventions in developing countries.

Among the articles analyzed, maternal health was the most prevalent health outcome with a frequency of 9 out of the 30 articles (30\%) [27-35]. Infectious diseases and chronic diseases were the second most prevalent health outcomes, with a frequency of each of 8 of 30 (27\%) articles [36,39-44,49-51]. The third most prevalent outcome was preventive health, occurring in 5 of 30 (17\%) articles [22,52-55].

The mHealth interventions identified in the literature were SMS only; SMS or phone calls and voice messages, or both SMS and phone call and voice messages; SMS phone app; multimedia messages for diagnosis; and a combination of SMS, smartphone app, and cellphones. We identified SMS in 28 of the 30 articles we analyzed (93\%). The use of SMS only was mentioned in 16 of 26 interventions (62\%) [28-31,35,37,38,40-43,45-47,50,52]. SMS with or without phone calls and voice messages was the second highest with a frequency of 4 of 26 interventions (15\%) $[22,32,39,53]$. Smartphone with the use of apps was the third most commonly mHealth used with a frequency of 3 of 26 interventions $(12 \%)[34,36,55]$. Interventions using multimedia messages had a frequency of 2 of $26(4 \%)$ [27,54]. Finally, the combination of SMS, smartphone app, and cell calls occurred in only 1 of 26 (4\%) interventions [33].

We classified the 73 barriers into 14 categories identified in the 30 articles. The categories are immature (or lack of) infrastructure $(10 / 73,14 \%)$, lack of equipment $(9 / 73,12 \%)$, technology gap $(9 / 73,12 \%)$, human resource issues $(7 / 73,10 \%)$, time or work conflict $(7 / 73,10 \%)$, cost $(6 / 73,8 \%)$, lack of public policy $(8 / 73,8 \%)$, literacy $(4 / 73,5 \%)$, language barriers $(4 / 73$, $5 \%)$, psychosocial issues $(4 / 73,5 \%)$ lack of training $(3 / 73,4 \%)$, concerns about privacy and confidentiality of information (2/73, 
$3 \%)$, lack of efficacy $(1 / 73,1 \%)$, and exposure of program $(1 / 73$, $1 \%)$.

Figure 2 provides a geographic distribution of the studies in the analyzed studies. Africa accounted for 16 of 30 (53\%) articles, Asia for 10 of 30 (33\%) articles, and South America for 3 of
$30(10 \%)$ articles; 1 article studied both Africa and South America (3\%).

Table 1 summarizes the following details of each article analyzed: study design, sample size, technological intervention, health outcome, barriers identified, and world region.

Figure 2. Location of studies of mobile health technologies to improve preventive health outcomes in developing countries, by region.

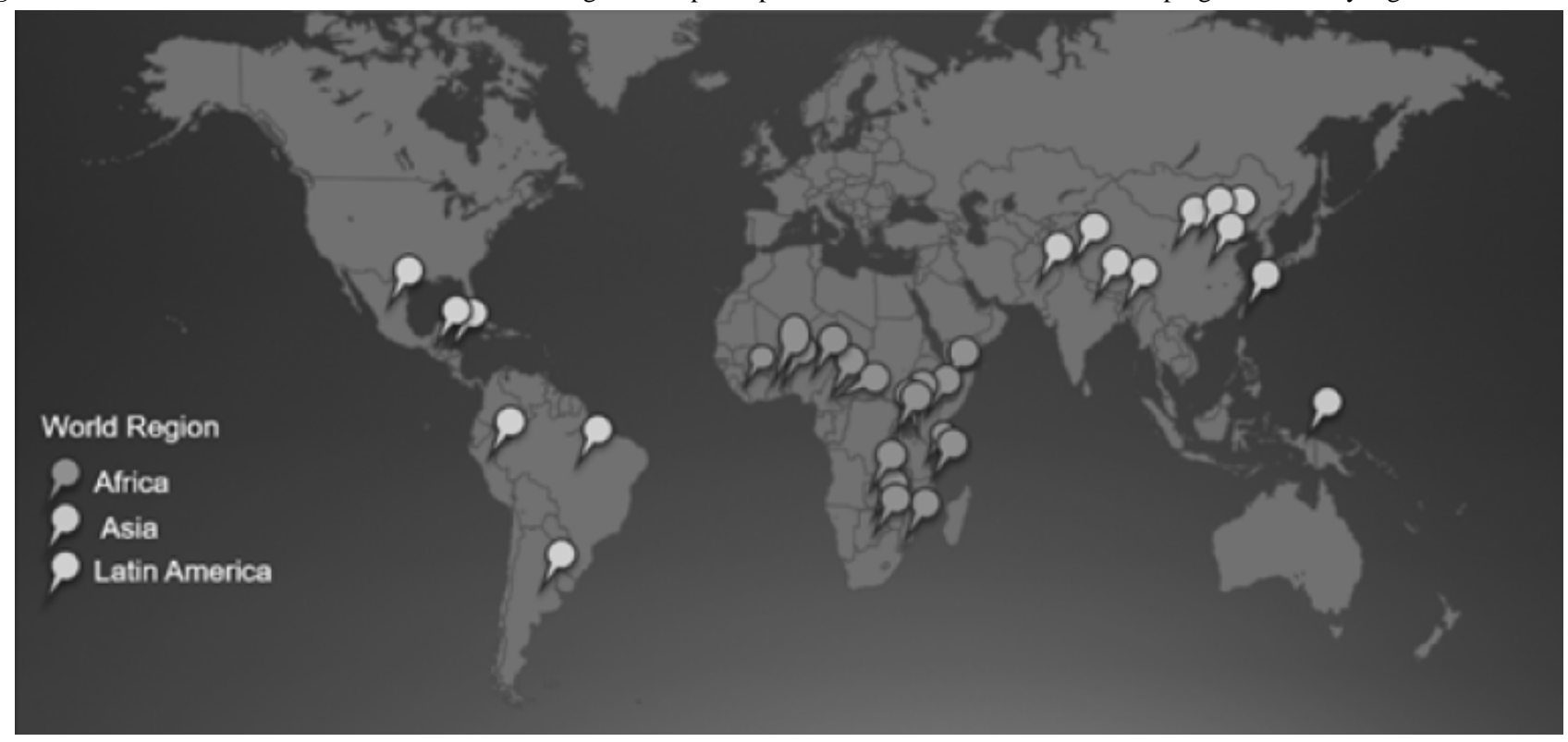


Table 1. Summary of results.

\begin{tabular}{|c|c|c|c|c|c|}
\hline $\begin{array}{l}\text { First author, date, } \\
\text { reference }\end{array}$ & $\begin{array}{l}\text { Study design and sample } \\
\text { size }\end{array}$ & $\begin{array}{l}\text { mHealth intervention } \\
\text { category }\end{array}$ & Health outcome category & Barriers identified & Continent \\
\hline Ginsburg, 2015 [36] & $\begin{array}{l}\text { Open data-kit survey (de- } \\
\text { sign-stage evaluation activi- } \\
\text { ty) }\end{array}$ & Smartphone app & Infectious disease & $\begin{array}{ll}- & \text { Technology gap } \\
\text { - } & \text { Language barrier }\end{array}$ & Africa \\
\hline Nhavoto, 2017 [37] & $\begin{array}{l}\mathrm{RCT}^{\mathrm{a}} \text { and interviews (tuber- } \\
\text { culosis } \mathrm{n}=69, \text { HIV } \mathrm{n}=72 \text { ) }\end{array}$ & SMS ${ }^{\mathrm{b}}$ only & Infectious disease & $\begin{array}{ll}\text { - } & \text { Privacy concerns } \\
\text { - } & \text { Literacy } \\
\text { - } & \text { Language barrier } \\
\text { Equipment }\end{array}$ & Africa \\
\hline Bediang, 2014 [38] & $\begin{array}{l}\text { Blinded RCT (intervention } \\
\mathrm{n}=104 \text {, control } \mathrm{n}=104 \text { ) }\end{array}$ & SMS only & Infectious disease & $\begin{array}{ll}\text { - } & \text { Infrastructure } \\
\text { - } & \text { Cost } \\
\text { - } & \text { Policy }\end{array}$ & Africa \\
\hline Bigna, 2013 [39] & $\begin{array}{l}\mathrm{RCT}(\mathrm{n}=224 \text { divided into } 4 \\
\text { groups) }\end{array}$ & $\begin{array}{l}\text { SMS with or without } \\
\text { phone calls and voice } \\
\text { mail }\end{array}$ & Infectious disease & $\begin{array}{ll}\text { - } & \text { Equipment } \\
\text { - } & \text { Language barrier } \\
\text { - } & \text { Policy } \\
\text { - } & \text { Privacy concerns } \\
\text { Infrastructure }\end{array}$ & Africa \\
\hline $\begin{array}{l}\text { Medhanyie, } 2015 \\
\text { [27] }\end{array}$ & $\begin{array}{l}\text { Interviews, } 2893 \text { electronic } \\
\text { health records of } 1122 \\
\text { women }\end{array}$ & $\begin{array}{l}\text { Multimedia messages } \\
\text { for diagnosis }\end{array}$ & Maternal health & $\begin{array}{ll}\text { - } & \text { Time or work conflict } \\
\text { - } & \text { Human resources issues } \\
\text { - } & \text { Time or work conflict } \\
\text { - } & \text { Time or work conflict }\end{array}$ & Africa \\
\hline Rokicki, 2017 [28] & Cluster RCT $(\mathrm{n}=756)$ & SMS only & Maternal health & $\begin{array}{ll}\text { - } & \text { Time or work conflict } \\
\text { - } & \text { Equipment } \\
\text { - } & \text { Cost }\end{array}$ & Africa \\
\hline Toda, 2016 [52] & $\begin{array}{l}\text { Clustered RCT (intervention } \\
\mathrm{n}=32[88 \text { cases], control } \\
\mathrm{n}=32[21 \text { cases }] \text { ) }\end{array}$ & SMS only & Preventive health & $\begin{array}{ll}\text { - } & \text { Human resources issues } \\
\text { - } & \text { Technology gap } \\
\text { - } & \text { Training }\end{array}$ & Africa \\
\hline Flax, 2017 [29] & $\begin{array}{l}\text { Cluster RCT and interviews } \\
(\mathrm{n}=195)\end{array}$ & SMS only & Maternal health & $\begin{array}{l}\text { - Infrastructure } \\
\text { - } \quad \text { Psychosocial stressors }\end{array}$ & Africa \\
\hline Ngabo, 2012 [30] & Pilot study & SMS only & Maternal health & $\begin{array}{ll}\text { - } & \text { Infrastructure } \\
\text { - } & \text { Equipment } \\
\text { - } & \text { Cost }\end{array}$ & Africa \\
\hline Jia, 2015 [53] & $\begin{array}{l}\text { Longitudinal data analysis } \\
\text { of monthly electronic health } \\
\text { record suspect and mortality } \\
\text { cases for both the traditional } \\
\text { sentinel program and mobile } \\
\text { phone reporting }(n=178)\end{array}$ & $\begin{array}{l}\text { SMS with or without } \\
\text { phone calls and voice } \\
\text { mail }\end{array}$ & Preventive health & - Training & Africa \\
\hline Leon, 2015 [40] & $\begin{array}{l}\mathrm{RCT}(\mathrm{n}=22 \text { studied, } \mathrm{n}=15 \\
\text { interviewed) }\end{array}$ & SMS only & Chronic disease & $\begin{array}{ll}\text { - } & \text { Technology gap } \\
\text { - } & \text { Infrastructure } \\
\text { - } & \text { Psychosocial stressors }\end{array}$ & Africa \\
\hline Hao, 2015 [41] & Interviews $(\mathrm{n}=11)$ & SMS only & Infectious disease & $\begin{array}{ll}\text { - } & \text { Time or work conflict } \\
\text { - } & \text { Equipment } \\
\text { - } & \text { Policy }\end{array}$ & Africa \\
\hline Lund, 2014 [31] & $\begin{array}{l}\text { Open-label, pragmatic-clus- } \\
\text { ter RCT, } 2550 \text { pregnant } \\
\text { women (intervention } \\
n=1311 \text {, control } n=1239 \text { ) }\end{array}$ & SMS only & Maternal health & $\begin{array}{ll}\text { - } & \text { Equipment } \\
\text { - } & \text { Literacy }\end{array}$ & Africa \\
\hline Tuijn, 2011 [54] & $\begin{array}{l}\text { Feasibility study attaching a } \\
\text { cell phone to a microscope }\end{array}$ & $\begin{array}{l}\text { Multimedia messages } \\
\text { for diagnosis }\end{array}$ & Preventive health & $\begin{array}{ll}\text { - } & \text { Infrastructure } \\
\text { - } & \text { Equipment } \\
\text { - } & \text { Training }\end{array}$ & Africa \\
\hline
\end{tabular}




\begin{tabular}{|c|c|c|c|c|c|}
\hline $\begin{array}{l}\text { First author, date, } \\
\text { reference }\end{array}$ & $\begin{array}{l}\text { Study design and sample } \\
\text { size }\end{array}$ & $\begin{array}{l}\text { mHealth intervention } \\
\text { category }\end{array}$ & Health outcome category & Barriers identified & Continent \\
\hline $\begin{array}{l}\text { Linnemayr, } 2017 \\
\text { [42] }\end{array}$ & True experiment $(n=332)$ & SMS only & Infectious disease & - $\quad$ Technology gap & Africa \\
\hline Steury, 2016 [43] & $\operatorname{RCT}(n=96)$ & SMS only & Chronic disease & $\begin{array}{ll}\text { - } & \text { Efficacy } \\
\text { - } & \text { Cost }\end{array}$ & Africa \\
\hline Ippoliti, 20107 [32] & $\operatorname{RCT}(\mathrm{n}=17)$ & $\begin{array}{l}\text { SMS with or without } \\
\text { phone calls and voice } \\
\text { mail }\end{array}$ & Maternal health & $\begin{array}{ll}\text { - } & \text { Infrastructure } \\
\text { - } & \text { Literacy }\end{array}$ & $\begin{array}{l}\text { Africa and } \\
\text { South } \\
\text { America }\end{array}$ \\
\hline Uddin, 2017 [33] & $\begin{array}{l}\text { Stratified } 2 \text {-stage random- } \\
\text { cluster sampling technique } \\
\text { to select participants } \\
(\mathrm{n}=5280)\end{array}$ & $\begin{array}{l}\text { SMS, smartphone app, } \\
\text { and cell phone calls }\end{array}$ & Maternal health & - $\quad$ Technology gap & Asia \\
\hline Fang, 2018 [44] & $\operatorname{RCT}(\mathrm{n}=247)$ & $\begin{array}{l}\text { SMS with or without } \\
\text { phone calls and voice } \\
\text { mail }\end{array}$ & Chronic disease & $\begin{array}{ll}\text { - } & \text { Technology gap } \\
\text { - } & \text { Equipment } \\
\text { - } & \text { Psychosocial stressors }\end{array}$ & Asia \\
\hline Zhou, 2016 [45] & $\begin{array}{l}\text { RCT and the intervention } \\
\text { period lasted for } 6 \text { months } \\
\text { and used baseline and fol- } \\
\text { low-up surveys ( } n=351 \text { vil- } \\
\text { lages, } n=1393 \text { children) }\end{array}$ & SMS only & Chronic disease & - $\quad$ Policy & Asia \\
\hline Fang, 2016 [46] & $\begin{array}{l}\text { Random sampling method } \\
\text { RCT ( } 3 \text { groups: SMS }[n=95] \\
\text { SMS + Micro Letter app } \\
[n=92], \text { and phone }[n=93])\end{array}$ & SMS only & Chronic disease & $\begin{array}{ll}\text { - } & \text { Technology gap } \\
\text { - } & \text { Infrastructure }\end{array}$ & Asia \\
\hline $\begin{array}{l}\text { Kumboyono, } 2017 \\
{[47]}\end{array}$ & $\begin{array}{l}\text { No RCT, posttest-only con- } \\
\text { trol group design }(n=90)\end{array}$ & SMS only & Infectious disease & - $\quad$ Psychosocial stressors & Asia \\
\hline Kazi, 2013 [48] & $\begin{array}{l}\text { No RCT, systematic random } \\
\text { sampling }(n=28)\end{array}$ & SMS only & Infectious disease & - Human resources issues & Asia \\
\hline Mohan, 2017 [49] & $\begin{array}{l}\text { Cross-sectional study } \\
(\mathrm{n}=800)\end{array}$ & SMS only & Chronic disease & - $\quad$ Language barrier & Asia \\
\hline Lin, 2017 [35] & True experiment $(\mathrm{n}=757)$ & SMS only & Maternal health & $\begin{array}{ll}\text { - } & \text { Training } \\
\text { - } & \text { Policy } \\
\text { - } & \text { Exposure of program } \\
\text { - } & \text { Time or work conflict }\end{array}$ & Asia \\
\hline Wu, 2014 [55] & $\begin{array}{l}\text { Prospective true experiment } \\
\text { (intervention } n=97 \text {, control } \\
n=128 \text { ) }\end{array}$ & Smartphone app & Preventive health & - $\quad \mathrm{N} / \mathrm{A}^{\mathrm{c}}$ & Asia \\
\hline $\begin{array}{l}\text { Beratarrechea, } 2015 \\
{[22]}\end{array}$ & Interviews $(\mathrm{n}=43)$ & $\begin{array}{l}\text { SMS with or without } \\
\text { phone calls and voice } \\
\text { mail }\end{array}$ & Preventive health & $\begin{array}{ll}\text { - } & \text { Infrastructure } \\
\text { - } & \text { Technology gap }\end{array}$ & $\begin{array}{l}\text { South } \\
\text { America }\end{array}$ \\
\hline Rico, 2017 [50] & Interviews $(n=14)$ & SMS only & Chronic disease & $\begin{array}{ll}\text { - } & \text { Literacy } \\
\text { - } & \text { Technology gap }\end{array}$ & $\begin{array}{l}\text { South } \\
\text { America }\end{array}$ \\
\hline Piette, 2012 [51] & $\operatorname{RCT}(n=200)$ & SMS only & Chronic disease & $\begin{array}{ll}\text { - } & \text { Cost } \\
\text { - } & \text { Equipment } \\
\text { - } & \text { Infrastructure } \\
\text { - } & \text { Policy }\end{array}$ & $\begin{array}{l}\text { South } \\
\text { America }\end{array}$ \\
\hline
\end{tabular}

${ }^{\mathrm{a}} \mathrm{RCT}$ : randomized controlled trial.

${ }^{\mathrm{b}} \mathrm{SMS}$ : short message service.

${ }^{\mathrm{c}} \mathrm{N} / \mathrm{A}$ : not available. 


\section{Discussion}

\section{Principal Findings}

This review identified the common barriers faced by developing countries in the adoption of mHealth. mHealth is widely used in developing countries as a tool to improve the health outcomes of highly vulnerable communities and individuals. Based on the evidence found in this review, mHealth is an effective method to support health care services. mHealth has been used in many developing countries in regions such as Africa, Asia, and Latin America. These countries constantly battle infectious diseases, chronic diseases, perinatal complications, acute diseases, birth defects, and many more. This review revealed important barriers that must be understood before implementing mHealth initiatives. Considering and assessing these barriers prior to the design phase of an mHealth intervention will have a positive impact on the health outcomes of populations and individuals.

As noted above, mHealth can provide a great opportunity to solve health care issues faced by developing countries. However, there are various challenges and barriers to be considered prior to implementation.

\section{Health Outcomes}

Based on the findings of this review, the 2 main health outcomes affected by an mHealth intervention were infectious diseases and maternal health. In developing countries, the burden of infectious diseases is prevalent due to poverty, leading to "poor nutrition, indoor air pollution and lack of access to proper sanitation, and lack of health education" [56]. According to the World Health Organization, most illnesses are avoidable and treatable. It is estimated that diseases account for up to $45 \%$ of the burden in poor countries due to poverty; HIV, tuberculosis, and malaria account for $18 \%$ [56]. The second most common health outcome affected by an mHealth intervention was maternal health. Developing countries account for $99 \%$ of all maternal deaths compared with developed countries [53]. This is the biggest health gap in the world [53]. In remote locations, poor women are more prone to receive inadequate care, specifically in the areas lacking skilled health care workers [27].

The majority of the reviewed articles used SMS as an mHealth intervention to improve infectious disease, health outcomes, and patient treatment adherence. In developing countries, infectious diseases are prevalent due to the lack of preventive care. mHealth interventions in developing countries were considered effective in improving antenatal care, vaccination, and preventive treatment for chronic and infectious diseases [55]. SMS was also effective for maternal health, prenatal care, infant care, HIV/AIDS prevention, treatment adherence, cardiovascular disease care, diabetes care, health education, tuberculosis prevention and care, anemia care, immunization, and disease awareness [32,49]. SMS directly increased disease awareness by providing health tips and reinforcing reminder systems. Moreover, SMS provided emotional support to patients, promoted knowledge about health, and influenced attitude change toward greater self-responsibility [36].

\section{Mobile Health Tool Used}

SMS was the most commonly used mHealth tool due to the number of mobile phones in use. An estimated 4.5 billion people are expected to have mobile phones worldwide by 2020 [33]. Compared with other methods of communication, text messaging has an advantage due to its low cost and high reliability [33]. Researchers in the field state that educational mHealth training programs are effective in raising awareness by offering an efficient and cost-effective way to achieve the success of mHealth implementation [42]. A health education approach via mobile phones can be used to manage diseases, aid medical testing, and improve treatments. Specifically, text messaging can be used for interventions and health education, because it is particularly popular in developing countries [42]. Through simple text messaging, patients have reported that they felt more confident in their treatment [49]. SMS has the potential to make patients feel supported, encouraged, and aware, thus helping them take better care of themselves and continue treatment [28]. SMS reminders also improve appointment attendance and SMS text messaging helps health care providers prescribe medicine on a timely basis, consequently improving patient care [32,39].

SMS is perceived as a tool that can boost the rate of adherence to medical treatment and has the potential to help in the prevention of diseases. Health information transmitted through text messages can also effectively be used to manage the treatment of infectious diseases such as tuberculosis [45]. The main mechanism is the use of text messages to remind patients about appointments and taking medications, to deliver motivational messages and health education or health promotion messages. Another approach is the use of mobile phones by health workers to help support services in diagnosing women and children in remote areas and identifying patients at risk who need to be referred. Throughout the literature review, SMS was often mentioned in combination with phone calls, voice messages, smartphone apps, and multimedia messages. However, the literature also provided examples of participants who did not know how to use mobile phones or similar technology efficiently. In other words, they did not know how to work a phone or were unable to read text messages. This limited knowledge may be attributed to the amount of exposure individuals in developing countries have to technology. Therefore, there was a correlation between frequency of phone usage and knowledge of this technology. Phone calls as an mHealth intervention can also help improve health outcomes while at the same time offering participants a simpler method than SMS. Mobile phone apps were proven to be an efficient tool to assist people in achieving early screening for diagnosis and treatment purposes. Moreover, apps have been shown to prevent health complications, thus helping improve preventive medicine [50].

\section{World Region}

Africa was the most frequent study setting in the articles we analyzed. This review suggested that this region has been extensively participating in mHealth projects.

The 3 most prevalent barrier categories were lack of infrastructure, lack of equipment, and technology gap. 
Developing countries should consider investing in their infrastructure and encouraging partnerships with equipment providers to help their populations afford phones and learn how to use them. It is vital for developing countries to adapt to new emerging technologies in an effort to reduce the risk of being left behind in the great technological advancements in health.

\section{Strengths and Limitations}

This review had several limitations. First, selection bias tended to be prevalent in many research studies. To help address this problem, we held consensus meetings once per week to discuss the findings of the research articles. However, our main controls for selection bias were (1) identifying the research objective, (2) defining the key terms used, and (3) having more than one reviewer examine each article. We conducted all consensus meetings either through Skype or in person. These meetings offered great value to our research because they reduced personal bias when eliminating the articles from the literature matrix. We gathered feedback, opinions, and knowledge throughout the process. Another selection bias was the selection of only free full-text articles. We eliminated a few articles in this step. Including those articles in the review most likely would not have changed the outcome of our review, but it might have identified additional barriers.

Second, we examined only 10 years' worth of articles when abstracting the data. However, this may or may not be a limitation, as the technology used in mHealth may not have existed earlier. A third possible limitation is publication bias for the 10 years considered in this review.

This review adds to the body of knowledge on the significant barriers mHealth confronts in developing countries. This review was constructed in accordance with PRISMA guidelines. We limited our review to 2 well-known research databases, CINAHL and PubMed. As a result, we expect this review will have a high external and internal validity.

\section{Recommendations and Suggestions for Further Research}

To overcome these barriers, the published literature suggested some important solutions. Strengthening health care systems through the use of mHealth requires strong governance, as well as the commitment of the private sector [35,48]. More investment in phones and rigorous training on these devices is also required to improve their acceptability in developing countries [47]. It is also important to consider the characteristics of the population, such as socioeconomic background, to gain a better perspective of the community [29]. When phone ownership is lacking, a microcredit program, in which several people can obtain a loan to purchase a group phone, may be feasible, and consequently the group would rely on other family members or the community to improve their health [37]. The successful development of interventions using the capability of mHealth technologies lies within the criticality of mHealth research. It entails important characteristics, such as collaboration throughout all phases of the project [43].

It is important to adapt and redesign emerging interventions as the technology advances. The future of mHealth in both developed and developing countries is expected to be prosperous with new innovations arising exponentially throughout the health care domain. It is important to assess the disparities by country in order to improve their respective health care sectors. Community needs could be addressed and improved through the use of available technology by country. However, to drastically make a change and improve the use of mHealth in developing countries, policy reform at all levels is needed.

Project leader support through policy reform could compensate for the barriers faced in developing countries. Therefore, there is a need for future research on how governments can help their countries reach their goals to improve and increase the acceptance of mHealth as a means to improve health care and, ultimately, improve the health of their communities. In addition, there is a need for future implementation of mHealth technologies such as text messaging to improve chronic diseases, such as tuberculosis, HIV, hypertension, cardiovascular disease, colorectal cancer, and pneumonia, in remote and resource-limited settings to overcome the challenges a community faces. Implementation of mHealth initiatives requires rigorous training of health care workers, as well as of the designated population who will be participants in studies, to understand and use the technology correctly [39].

Training on the use of devices, such as cell phones and mobile apps, and on sharing and receiving text messages will not only improve the performance but also increase the acceptability of mHealth within the community $[39,46]$. Special attention needs to be paid to the illiterate when using SMS due to the inability of participants to read and comprehend these messages [55]. Lastly, there is a need to design the health system based on approaches to control the timing of text messaging, mobile network fluctuations, and mobile phone turnovers to improve treatment adherence and follow-up visits in cases of chronic diseases, infectious diseases, maternal care, and birth defects $[32,48]$.

\section{Conclusion}

The published literature demonstrates the barriers faced by developing countries in the use of mHealth to improve health outcomes. This systematic review shed light on the most prominent health outcomes that can be improved using mHealth technology interventions in developing countries. SMS technology is readily available at low cost in developing countries and can be easily adopted to interventions that improve the health outcomes already identified. Additionally, the barriers identified will provide the leaders of future intervention projects a solid foundation for the design of those interventions, thus increasing the chances of long-term success and sustainability. We suggest that, to overcome the top 3 barriers, project leaders who wish to implement mHealth interventions must establish partnerships with local governments and nongovernmental organizations to secure funding, leadership, and the required infrastructure. This research identified the barriers and the frequency of those barriers by region. It also identified the most used type of mHealth tool, as well as the health outcomes affected by the tool used. This literature review highlighted the need for policy reform in developing countries to improve health care and, ultimately, improve the health of their communities. 


\section{Acknowledgments}

The authors received no financial support for the research, authorship, or publication of this paper.

\section{Conflicts of Interest}

None declared.

\section{Multimedia Appendix 1}

Preferred Reporting Items for Systematic Reviews and Meta-Analyses (PRISMA) checklist.

[PDF File (Adobe PDF File), 67 KB-Multimedia Appendix 1]

\section{Multimedia Appendix 2}

Key terms used in the search string. [PDF File (Adobe PDF File), 22 KB-Multimedia Appendix 2]

\section{References}

1. Pillay Y, Motsoaledi PA. Digital health in South Africa: innovating to improve health. BMJ Glob Health 2018;3(Suppl 2):e000722 [FREE Full text] [doi: 10.1136/bmjgh-2018-000722] [Medline: 29713513]

2. Seebregts C, Fogwill T, Tanna G, Barron P, Benjamin P. MomConnect: an exemplar implementation of the health normative standards framework in South Africa. South Afr Health Rev 2016 Jan 01;2016(1):125-135 [FREE Full text]

3. McBride B, Nguyen LT, Wiljer D, Vu NC, Nguyen CK, O'Neil J. Development of a maternal, newborn and child mHealth intervention in Thai Nguyen Province, Vietnam: protocol for the mMom Project. JMIR Res Protoc 2018 Jan 11;7(1):e6 [FREE Full text] [doi: 10.2196/resprot.7912] [Medline: 29326095]

4. Odetola TD, Ayamolowo LB, Ayamolowo SJ. Childbearing women's perception about the use of mHealth for maternal health information in rural communities, Ile-Ife, Nigeria. J Int Soc Telemed eHealth 2018 May 08;6(1):9-1 [FREE Full text] [doi: $10.29086 / \mathrm{JISfTeH} .6 . \mathrm{e} 9]$

5. Kay M, Santos J, Takane M. mHealth: new horizons for health through mobile technologies. Global Observatory for eHealth series. Volume 3. Geneva, Switzerland: World Health Organization; 2011. URL: https://apps.who.int/iris/bitstream/handle/ 10665/44607/9789241564250 eng.pdf;jsessionid=FB42680AE27DBD769D572E8EC3ED937C?sequence=1 [accessed 2019-08-16]

6. Uddin MJ, Shamsuzzaman M, Horng L, Labrique A, Vasudevan L, Zeller K, et al. Use of mobile phones for improving vaccination coverage among children living in rural hard-to-reach areas and urban streets of Bangladesh. Vaccine 2016 Jan 04;34(2):276-283 [FREE Full text] [doi: 10.1016/j.vaccine.2015.11.024] [Medline: 26647290]

7. Domek GJ, Contreras-Roldan IL, Asturias EJ, Bronsert M, Bolaños Ventura GA, O'Leary ST, et al. Characteristics of mobile phone access and usage in rural and urban Guatemala: assessing feasibility of text message reminders to increase childhood immunizations. Mhealth 2018;4:9 [FREE Full text] [doi: 10.21037/mhealth.2018.03.05] [Medline: 29780812]

8. Wang X, Luo R, Liu C, Zhang L, Yue A, Medina A, et al. Using daily text messages to improve adherence to infant micronutrient powder (MNP) packets in rural western China: a cluster-randomized controlled trial. PLoS ONE 2018 Jan 19;13(1):e0191549. [doi: 10.1371/journal.pone.0191549] [Medline: 29352304]

9. Sutcliffe CG, Thuma PE, van Dijk JH, Sinywimaanzi K, Mweetwa S, Hamahuwa M, et al. Use of mobile phones and text messaging to decrease the turnaround time for early infant HIV diagnosis and notification in rural Zambia: an observational study. BMC Pediatr 2017 Mar 08;17(1):66 [FREE Full text] [doi: 10.1186/s12887-017-0822-z] [Medline: 28270134]

10. Krishnan A, Ferro EG, Weikum D, Vagenas P, Lama JR, Sanchez J, et al. Communication technology use and mHealth acceptance among HIV-infected men who have sex with men in Peru: implications for HIV prevention and treatment. AIDS Care 2015;27(3):273-282 [FREE Full text] [doi: 10.1080/09540121.2014.963014] [Medline: 25285464]

11. Albino S, Tabb KM, Requena D, Egoavil M, Pineros-Leano MF, Zunt JR, et al. Perceptions and acceptability of short message services technology to improve treatment adherence amongst tuberculosis patients in Peru: a Focus Group Study. PLoS One 2014;9(5):e95770 [FREE Full text] [doi: 10.1371/journal.pone.0095770] [Medline: 24828031]

12. Snyders FJ. Determining the Feasibility of Using Mobile Phones to Strengthen the Information Management of Preventative Health Care in South Africa [master's thesis]. Stellenbosch, South Africa: Stellenbosch University; 2013.

13. World Health Organization. Maternal mortality. Geneva, Switzerland: WHO; 2018. URL: https://www.who.int/en/news-room/ fact-sheets/detail/maternal-mortality [accessed 2018-12-01] [WebCite Cache ID 74Knn43Yc]

14. Déglise C, Suggs LS, Odermatt P. SMS for disease control in developing countries: a systematic review of mobile health applications. J Telemed Telecare 2012;18(5):273-281. [doi: 10.1258/jtt.2012.110810] [Medline: 22826375]

15. Wu Q, Zhang Y, Chang S, Wang W, van Velthoven MH, Han H, et al. Monitoring and evaluating the adherence to a complementary food supplement (Ying Yang Bao) among young children in rural Qinghai, China: a mixed methods evaluation study. J Glob Health 2017 Jun;7(1) [FREE Full text] [doi: 10.7189/jogh.07.011101] [Medline: 28702176] 
16. Farach N, Faba G, Julian S, Mejía F, Cabieses B, D'Agostino M, et al. Stories from the field: the use of information and communication technologies to address the health needs of underserved populations in Latin America and the Caribbean. JMIR Public Health Surveill 2015;1(1):e1 [FREE Full text] [doi: 10.2196/publichealth.4108] [Medline: 27227124]

17. Oliveira-Ciabati L, Vieira CS, Franzon ACA, Alves D, Zaratini FS, Braga GC, et al. PRENACEL - a mHealth messaging system to complement antenatal care: a cluster randomized trial. Reprod Health 2017 Nov 07;14(1):146 [FREE Full text] [doi: 10.1186/s12978-017-0407-1] [Medline: 29116028]

18. Rajan JV, Moura J, Gourley G, Kiso K, Sizilio A, Cortez AM, et al. Understanding the barriers to successful adoption and use of a mobile health information system in a community health center in São Paulo, Brazil: a cohort study. BMC Med Inform Decis Mak 2016 Nov 17;16(1):146 [FREE Full text] [doi: 10.1186/s12911-016-0385-1] [Medline: 27855685]

19. Vieira EM, Vieira CS, Bonifácio LP, de Oliveira Ciabati LM, Franzon AC, Zaratini FS, et al. PRENACEL: development and evaluation of an m-health strategy to improve prenatal care in Brazil. Health 2016 Aug 01;15:16. [doi:

$\underline{10.5281 / \text { zenodo.1126866] }}$

20. McCarthy OL, Wazwaz O, Osorio Calderon V, Jado I, Saibov S, Stavridis A, et al. Development of an intervention delivered by mobile phone aimed at decreasing unintended pregnancy among young people in three lower middle income countries. BMC Public Health 2018 May 02;18(1):576 [FREE Full text] [doi: 10.1186/s12889-018-5477-7] [Medline: 29716571]

21. Diez-Canseco F, Toyama M, Ipince A, Perez-Leon S, Cavero V, Araya R, et al. Integration of a technology-based mental health screening program into routine practices of primary health care services in Peru (the Allillanchu Project): development and implementation. J Med Internet Res 2018 Mar 15;20(3):e100 [FREE Full text] [doi: 10.2196/jmir.9208] [Medline: 29588272]

22. Beratarrechea A, Diez-Canseco F, Fernández A, Kanter R, Letona P, Martinez H, et al. [Acceptability of a mobile health based intervention to modify lifestyles in prehypertensive patients in Argentina, Guatemala and Peru: a pilot study]. Rev Peru Med Exp Salud Publica 2015;32(2):221-229 [FREE Full text] [Medline: 26338378]

23. Moher D, Liberati A, Tetzlaff J, Altman DG, PRISMA Group. Preferred reporting items for systematic reviews and meta-analyses: the PRISMA statement. Int J Surg 2010;8(5):336-341 [FREE Full text] [doi: 10.1016/j.ijsu.2010.02.007] [Medline: 20171303]

24. Shea BJ, Grimshaw JM, Wells GA, Boers M, Andersson N, Hamel C, et al. Development of AMSTAR: a measurement tool to assess the methodological quality of systematic reviews. BMC Med Res Methodol 2007 Feb 15;7:10 [FREE Full text] [doi: 10.1186/1471-2288-7-10] [Medline: 17302989]

25. Light RJ. Measures of response agreement for qualitative data: Some generalizations and alternatives. Psychol Bull 1971;76(5):365-377. [doi: $10.1037 / \mathrm{h} 0031643$ ]

26. McHugh ML. Interrater reliability: the kappa statistic. Biochem Med (Zagreb) 2012;22(3):276-282 [FREE Full text] [Medline: 23092060]

27. Medhanyie AA, Little A, Yebyo H, Spigt M, Tadesse K, Blanco R, et al. Health workers' experiences, barriers, preferences and motivating factors in using mHealth forms in Ethiopia. Hum Resour Health 2015 Jan 15;13:2 [FREE Full text] [doi: 10.1186/1478-4491-13-2] [Medline: 25588973]

28. Rokicki S, Cohen J, Salomon JA, Fink G. Impact of a text-messaging program on adolescent reproductive health: a cluster-randomized trial in Ghana. Am J Public Health 2017 Feb;107(2):298-305. [doi: 10.2105/AJPH.2016.303562] [Medline: 27997236]

29. Flax VL, Ibrahim AU, Negerie M, Yakubu D, Leatherman S, Bentley ME. Group cell phones are feasible and acceptable for promoting optimal breastfeeding practices in a women's microcredit program in Nigeria. Matern Child Nutr 2017 Jan;13(1):1 [FREE Full text] [doi: 10.1111/mcn.12261] [Medline: 26990786]

30. Ngabo F, Nguimfack J, Nwaigwe F, Mugeni C, Muhoza D, Wilson DR, et al. Designing and implementing an innovative SMS-based alert system (RapidSMS-MCH) to monitor pregnancy and reduce maternal and child deaths in Rwanda. Pan Afr Med J 2012;13:31 [FREE Full text] [Medline: 23330022]

31. Lund S, Nielsen BB, Hemed M, Boas IM, Said A, Said K, et al. Mobile phones improve antenatal care attendance in Zanzibar: a cluster randomized controlled trial. BMC Pregnancy Childbirth 2014 Jan 17;14:29 [FREE Full text] [doi: 10.1186/1471-2393-14-29] [Medline: 24438517]

32. Ippoliti NB, L'Engle K. Meet us on the phone: mobile phone programs for adolescent sexual and reproductive health in low-to-middle income countries. Reprod Health 2017 Jan 17;14(1):11 [FREE Full text] [doi: 10.1186/s12978-016-0276-z] [Medline: 28095855]

33. Uddin J, Biswas T, Adhikary G, Ali W, Alam N, Palit R, et al. Impact of mobile phone-based technology to improve health, population and nutrition services in Rural Bangladesh: a study protocol. BMC Med Inform Decis Mak 2017 Jul 06;17(1):101 [FREE Full text] [doi: 10.1186/s12911-017-0502-9] [Medline: 28683742]

34. Balakrishnan R, Gopichandran V, Chaturvedi S, Chatterjee R, Mahapatra T, Chaudhuri I. Continuum of care services for maternal and child health using mobile technology-a health system strengthening strategy in low and middle income countries. BMC Med Inform Decis Mak 2016 Jul 07;16:84 [FREE Full text] [doi: 10.1186/s12911-016-0326-z] [Medline: $\underline{27387548]}$

35. Lin Q, Yang L, Li F, Qin H, Li M, Chen J, et al. A village - based intervention: promoting folic acid use among rural Chinese women. Nutrients 2017 Feb 21;9(2):1 [FREE Full text] [doi: 10.3390/nu9020174] [Medline: 28230798] 
36. Ginsburg AS, Delarosa J, Brunette W, Levari S, Sundt M, Larson C, et al. mPneumonia: development of an innovative mHealth application for diagnosing and treating childhood pneumonia and other childhood illnesses in low-resource settings. PLoS One 2015;10(10):e0139625 [FREE Full text] [doi: 10.1371/journal.pone.0139625] [Medline: 26474321]

37. Nhavoto JA, Grönlund $\AA$, Klein GO. Mobile health treatment support intervention for HIV and tuberculosis in Mozambique: Perspectives of patients and healthcare workers. PLoS One 2017;12(4):e0176051 [FREE Full text] [doi:

10.1371/journal.pone.0176051] [Medline: 28419149]

38. Bediang G, Stoll B, Elia N, Abena J, Nolna D, Chastonay P, et al. SMS reminders to improve the tuberculosis cure rate in developing countries (TB-SMS Cameroon): a protocol of a randomised control study. Trials 2014 Jan 24;15:35 [FREE Full text] [doi: 10.1186/1745-6215-15-35] [Medline: 24460827]

39. Bigna JJR, Kouanfack C, Noubiap JJN, Plottel CS, Koulla-Shiro S. A randomized blinded controlled trial of mobile phone reminders on the follow-up medical care of HIV-exposed and HIV-infected children in Cameroon: study protocol (MORE CARE). Trials 2013 Sep 25;14:313 [FREE Full text] [doi: 10.1186/1745-6215-14-313] [Medline: 24066735]

40. Leon N, Surender R, Bobrow K, Muller J, Farmer A. Improving treatment adherence for blood pressure lowering via mobile phone SMS-messages in South Africa: a qualitative evaluation of the SMS-text Adherence SuppoRt (StAR) trial. BMC Fam Pract 2015 Jul 03;16:80 [FREE Full text] [doi: 10.1186/s12875-015-0289-7] [Medline: 26137844]

41. Hao W, Hsu Y, Chen K, Li H, Iqbal U, Nguyen P, et al. LabPush: a pilot study of providing remote clinics with laboratory results via short message service (SMS) in Swaziland, Africa - a qualitative study. Comput Methods Programs Biomed 2015 Jan;118(1):77-83. [doi: 10.1016/j.cmpb.2014.10.005] [Medline: 25453385]

42. Linnemayr S, Huang H, Luoto J, Kambugu A, Thirumurthy H, Haberer JE, et al. Text messaging for improving antiretroviral therapy adherence: no effects after 1 year in a randomized controlled trial among adolescents and young adults. Am J Public Health 2017 Dec;107(12):1944-1950. [doi: 10.2105/AJPH.2017.304089] [Medline: 29048966]

43. Steury EE. Mobile phone short message service to improve malaria pharmacoadherence in Zambia. J Nurs Scholarsh 2016 Jul;48(4):354-361. [doi: 10.1111/jnu.12216] [Medline: 27145248]

44. Fang R, Deng X. Electronic messaging intervention for management of cardiovascular risk factors in type 2 diabetes mellitus: a randomised controlled trial. J Clin Nurs 2018 Feb;27(3-4):612-620. [doi: 10.1111/jocn.13962] [Medline: 28700102]

45. Zhou H, Sun S, Luo R, Sylvia S, Yue A, Shi Y, et al. Impact of text message reminders on caregivers' adherence to a home fortification program against child anemia in rural western China: a cluster-randomized controlled trial. Am J Public Health $2016 \mathrm{Jul}$;106(7):1256-1262. [doi: 10.2105/AJPH.2016.303140] [Medline: 27077354]

46. Fang R, Li X. Electronic messaging support service programs improve adherence to lipid-lowering therapy among outpatients with coronary artery disease: an exploratory randomised control study. J Clin Nurs 2016 Mar;25(5-6):664-671. [doi: 10.1111/jocn.12988] [Medline: 26522838]

47. Kumboyono. Short message service as an alternative in the drug consumption evaluation of persons with tuberculosis in Malang, Indonesia. Jpn J Nurs Sci 2017 Apr;14(2):112-116. [doi: 10.1111/jjns.12140] [Medline: 27412502]

48. Kazi AM, Murtaza A, Khoja S, Zaidi AK, Ali SA. Monitoring polio supplementary immunization activities using an automated short text messaging system in Karachi, Pakistan. Bull World Health Organ 2014 Mar 01;92(3):220-225 [FREE Full text] [doi: 10.2471/BLT.13.122564] [Medline: 24700982]

49. Mohan B, Sharma S, Sharma S, Kaushal D, Singh B, Takkar S, et al. Assessment of knowledge about healthy heart habits in urban and rural population of Punjab after SMS campaign-a cross-sectional study. Indian Heart J 2017;69(4):480-484 [FREE Full text] [doi: 10.1016/j.ihj.2017.05.007] [Medline: 28822515]

50. Rico TM, Dos Santos Machado K, Fernandes VP, Madruga SW, Noguez PT, Barcelos CRG, et al. Text messaging (SMS) helping cancer care in patients undergoing chemotherapy treatment: a pilot study. J Med Syst 2017 Oct 09;41(11):181. [doi: 10.1007/s10916-017-0831-3] [Medline: 28990135]

51. Piette JD, Datwani H, Gaudioso S, Foster SM, Westphal J, Perry W, et al. Hypertension management using mobile technology and home blood pressure monitoring: results of a randomized trial in two low/middle-income countries. Telemed J E Health 2012 Oct;18(8):613-620 [FREE Full text] [doi: 10.1089/tmj.2011.0271] [Medline: 23061642]

52. Toda M, Njeru I, Zurovac D, O-Tipo S, Kareko D, Mwau M, et al. Effectiveness of a mobile short-message-service-based disease outbreak alert system in Kenya. Emerg Infect Dis 2016 Apr 1;22(4):711-715 [FREE Full text] [doi: 10.3201/eid2204.151459] [Medline: 26981628]

53. Jia K, Mohamed K. Evaluating the use of cell phone messaging for community Ebola syndromic surveillance in high risked settings in Southern Sierra Leone. Afr Health Sci 2015 Sep;15(3):797-802 [FREE Full text] [doi: 10.4314/ahs.v15i3.13] [Medline: 26957967]

54. Tuijn CJ, Hoefman BJ, van Beijma H, Oskam L, Chevrollier N. Data and image transfer using mobile phones to strengthen microscopy-based diagnostic services in low and middle income country laboratories. PLoS One 2011;6(12):e28348 [FREE Full text] [doi: 10.1371/journal.pone.0028348] [Medline: 22194829]

55. Wu HC, Chang CJ, Lin CC, Tsai MC, Chang CC, Tseng MH. Developing screening services for colorectal cancer on Android smartphones. Telemed J E Health 2014 Aug;20(8):687-695 [FREE Full text] [doi: 10.1089/tmj.2013.0288] [Medline: 24848873]

56. Luchetti M. Global health and the 10/90 gap. Br J Med Pract 2014 Dec 01;7(4):a731 [FREE Full text] 


\section{Abbreviations}

MeSH: Medical Subject Headings

mHealth: mobile health

PRISMA: Preferred Reporting Items for Systematic Reviews and Meta-Analyses

SMS: short message service

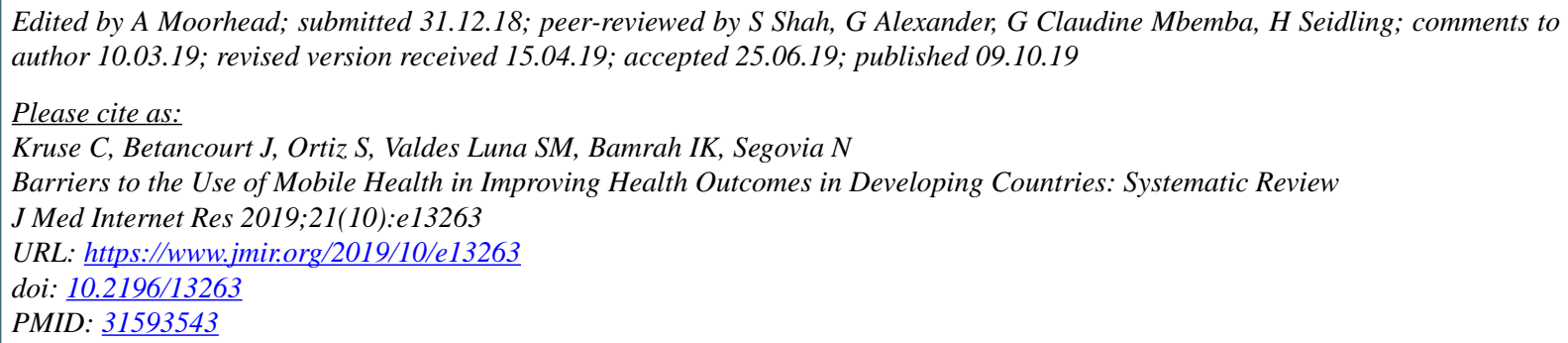

(C) Clemens Scott Kruse, Jose Betancourt, Stephanie Ortiz, Susana Melissa Valdes Luna, Inderdeep Kaur Bamrah, Narce Segovia. Originally published in the Journal of Medical Internet Research (http://www.jmir.org), 09.10.2019. This is an open-access article distributed under the terms of the Creative Commons Attribution License (https://creativecommons.org/licenses/by/4.0/), which permits unrestricted use, distribution, and reproduction in any medium, provided the original work, first published in the Journal of Medical Internet Research, is properly cited. The complete bibliographic information, a link to the original publication on http://www.jmir.org/, as well as this copyright and license information must be included. 